\title{
Hypomelanosis of Ito: streaks and whorls
}

\author{
Daisy Khera, ${ }^{01}$ Saurabh Singh, ${ }^{2}$ Priya Gupta ${ }^{1}$
}

'Department of Pediatrics, All India Institute of Medical Sciences, Jodhpur, Rajasthan, India

${ }^{2}$ Department of Dermatology, Venereology and Leprosy, All India Institute of Medical Sciences, Jodhpur, Rajasthan, India

\section{Correspondence to} Dr Daisy Khera,

pushpinderdaisy@gmail.com

Accepted 1 April 2019

\section{DESCRIPTION}

A 6-year-old male child presented to our department with delayed developmental milestones and generalised hypopigmented patches since birth. There was no history of seizures or hearing or visual deficit. Family history was not significant. Examination revealed symmetrical hypopigmented patches arranged linearly, involving predominantly the trunk and upper limbs and were following Blaschko's lines (figure 1). Anthropometry and the rest of the examination were normal. The child was diagnosed with hypomelanosis of Ito. Hearing assessment was normal. There were no ocular or dental abnormalities. Brain MRI showed mildly enlarged left hemisphere with dilatation of left lateral ventricle (figure 2). The overall IQ of the patient was found to be 46 , indicative of moderate level of intellectual disability with specific speech delay. The parents were counselled about the current level of intellectual functioning, asked to give opportunity to the child for learning self-help skills and referred to a speech therapist.

Hypomelanosis of Ito is a rare neuroectodermal disorder often associated with mental retardation and epilepsy. It is characterised by skin abnormalities in the form of unilateral or bilateral cutaneous macular hypopigmented whorls, streaks and patches, corresponding to Blaschko's lines. Various chromosomal anomalies have been identified in some patients and the current consensus is that the phenotype of hyperpigmentation or

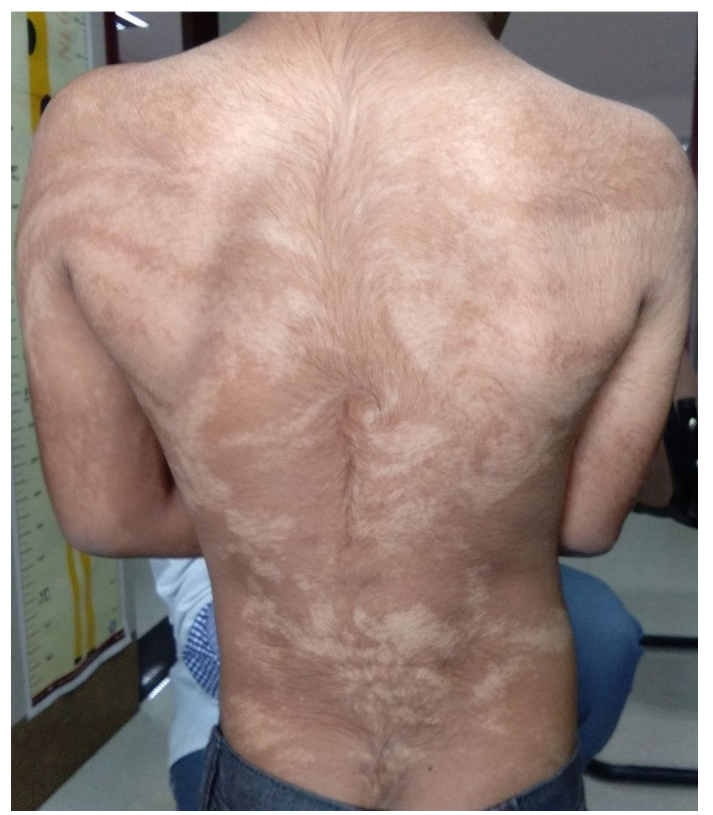

Figure 1 Hypopigmented patches arranged linearly and in whorls along Blaschko's lines over the back and upper limbs.

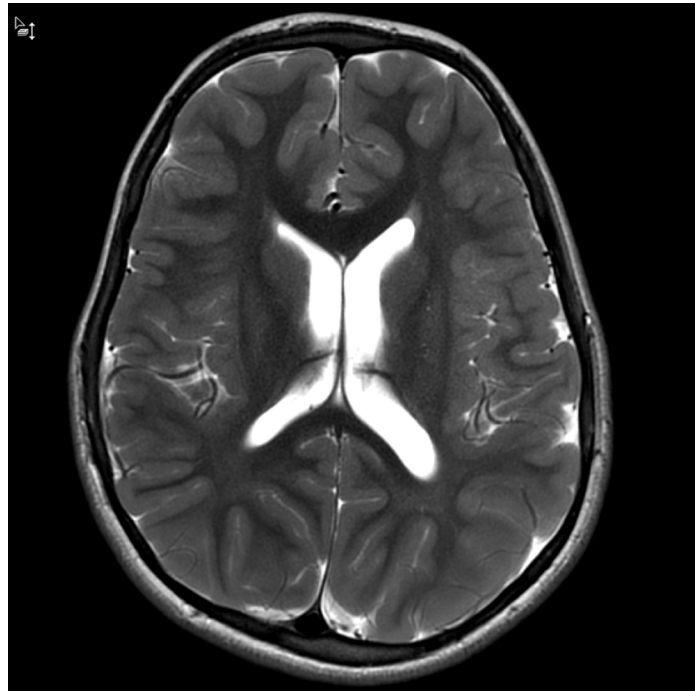

Figure 2 Brain MRI showing mild enlargement of left hemisphere with dilatation of left lateral ventricle.

hypopigmentation following Blaschko's lines occurs due to cutaneous mosaicism, either for a monogenic or a chromosomal disorder. ${ }^{1}$

The nervous system is the most commonly affected system in the form of intellectual disability (70\%), seizures (40\%), microcephaly $(25 \%)$ and muscular hypotonia (15\%). The musculoskeletal system is the second most frequently involved system, affected by scoliosis and thoracic and limb deformities. Twenty-five per cent of patients have minor ophthalmologic defects (strabismus, nystagmus) and $10 \%$ have cardiac defects. ${ }^{2}$

The brain MRI commonly reveals diffuse white matter abnormalities (>50\%) mainly in the parietal,

Learning points

Cutaneous markers should be looked for in all cases of developmental delay even if there is no history of seizure disorder.

- Neurocutaneous disorders like neurofibromatosis, tuberous sclerosis complex, Sturge-Weber syndrome, Von HippelLindau disease, incontinentia pigmenti and hypomelanosis of Ito primarily affect the skin and central nervous system but also affect several other organ systems and can be diagnosed bedside by an observant clinician.

- In all neurocutaneous disorders we should screen for musculoskeletal, ophthalmologic, cardiac, hearing, dental and renal abnormalities so that a multidisciplinary approach of management can be planned. 
periventricular and subcortical white matter of both hemispheres, either in the form of cystic-like lesions or altered/delayed myelination, generalised cerebral, brainstem, or cerebellar atrophy and/ or dilatation of cerebral ventricles and hemispheric asymmetry (both hemimegalencephaly and hemiatrophy). ${ }^{3}$

Contributors DK, SS and PG made substantial contributions to the conception and drafting of the work and revising it critically for important intellectual content. All authors gave final approval of the version to be published and agreed to be accountable for all aspects of the work in ensuring that questions related to the accuracy or integrity of any part of the work are appropriately investigated and resolved.

Funding The authors have not declared a specific grant for this research from any funding agency in the public, commercial or not-for-profit sectors. No funding or grant received from any funding agency
Competing interests None declared.

Patient consent for publication Parental/guardian consent obtained.

Provenance and peer review Not commissioned; externally peer reviewed.

\section{REFERENCES}

1 Taïeb A, Picard FM, Ezzedine K. et a/Genetic disorders of pigmentation. In: Griffiths C, Barker J, Bleiker T, Chalmers R, Creamer D, . eds. Rook's textbook of dermatology. 9th edn. Oxford: Wiley-Blackwell, 2016.

2 Galbraith SS, lesions H. In: Kliegman S, St Geme S, Nelson textbook of paediatrics. $20^{\text {th }}$ ed. Philadelphia: Elsevier, 2016:3138-9.

3 Kentab AY, Hassan HH, Hamad MH, et al. The neurologic aspects of hypomelanosis of Ito: Case report and review of the literature. Sudan J Paediatr 2014; 14:61-70

Copyright 2019 BMJ Publishing Group. All rights reserved. For permission to reuse any of this content visit

https://www.bmj.com/company/products-services/rights-and-licensing/permissions/

BMJ Case Report Fellows may re-use this article for personal use and teaching without any further permission.

Become a Fellow of BMJ Case Reports today and you can:

- Submit as many cases as you like

- Enjoy fast sympathetic peer review and rapid publication of accepted articles

- Access all the published articles

- Re-use any of the published material for personal use and teaching without further permission

For information on Institutional Fellowships contact consortiasales@bmjgroup.com

Visit casereports.bmj.com for more articles like this and to become a Fellow 